\title{
Use of Vastu Purush Mandala in Architectural Education
}

\author{
Aniruddha Naik , Dr. Uttam Kalawane \\ MIT Collage Aurangabad (MH), India \\ Dr. Babasaheb Ambedkar Marathwada University Aurangabad
}

\begin{abstract}
This paper is based upon the study of linkages between the traditional design knowledge concepts and the current Architectural education system in India. Especially the Vastu Purush Mandala, which is more relevant for today's architectural education. Vastu Purush Mandala will fill up the missing gap of theoretical components in contemporary architectural pedagogy. The importance of these ancestral architectural design principles and practices of architectural design has been neglected by current education systems. All the architectural principles and philosophy of architecture are explained in detail in various ancient Vedic treatises on Vastu Shastra. Linkages between various analytical indicators between classical architectural principles and current architectural principles are necessary.
\end{abstract}

The conventional way of studying architectural design is easier as it is linked with nature, cosmos, astrology, and spiritual life. The current architectural education system will be easy to understand with the help of traditional systems or principles. These long-established architectural principles do not depend upon any mechanical part for its material and strength testing. Soil testing is a good example of it, in the Vedic age architectural study the strength of soil is tested by smell, taste, and look. Sthapati (Architect) fills a small pit with water on-site and as per the ratio of time and percolation of water; he identifies the strength of soil and suggests the load-bearing capacity of the soil. This paper does not say that contemporary methods for testing are not necessary but ancestral methods are easier and have quick results to start the design and construction. There are other criteria also for small buildings and multi-storeyed buildings and its various formulas give quick results for planning. The most important part of the Vedic architectural system is the

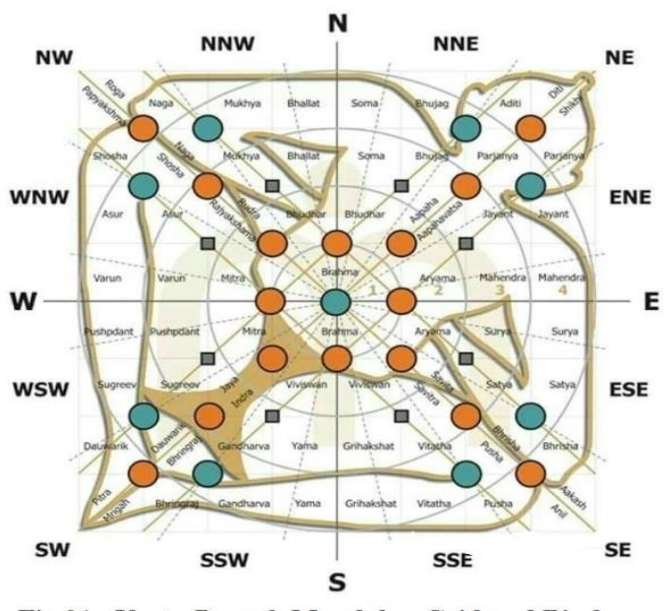

Fig 01 - Vastu Purush Mandala - Grid and Bindu (Intersection Point of grids) Format
Vastu Purush Mandala, in which all the day-to-day activity and its related spaces are given in a coded chart of squares. The Vastu Purush Mandala is a beautiful combination of climate, cosmos, spiritual life, and astrology. That's why the Vastu Purush Mandala has multi-dimensional qualities and is the most important tool for philosophy and practical use in current architectural education.

Vastu Purush Mandala is a readily applicable tool for the architectural education system and will help literate newcomers in the architectural field as Mandala is a symbolic representation of their day-to-day life. An interesting thing is that when any person comes to plan a house or building he 
remembers the architect to use Vastu Shastra principles in his building. Common man's demand for the use of ancestral building science is much more. All the spiritual treatises and texts are mentioned about "Vishvakarma", (God of creations). The current education system does not provide this knowledge to the students which will be required in his / her architectural practice. It is a paradox that a non-technical person, having this ancestral knowledge of Vastu Shastra (Architecture) plays an important role in designing a building. The study of Vastu Purush Mandala will provide a value-added education to the architects to design and construct buildings with proper circulation and proportion and it will also be beneficial to fulfill the demand of use of Vastu Shastra by a common man.

\section{Keywords}

Vastu Purush Mandala, Traditional Architectural education, Vedic architecture, Architectural design concept, Architectural philosophy, Indian architecture, Vedic architectural pedagogy.

\section{Introduction}

In Vedic treatises and texts, the traditional knowledge is codified in texts, figures, and yantras (geometric figures). Vastu Shastra is a science used for any type of creation of civil work and used to build buildings, dams, temples, gardens, palaces, etc. These treatises are thousand years old and based on experience and practical use by people and society, and their effects on lifestyle and health. In ancient times the master builder was called "Sthapati" and he had a team of "Sutragrahan" (draftsman), "Takshaka" (Stone/woodcarver), "Vardhakin" (Expert in Joinery). (Ramraz 1972). Sthapati should know Mathematics, Astrology and Vedas, and other construction-based treatises. Sthapati was given special attention by others as he is a creator of buildings (symbolically creator of Universe and his god is known as "Vishvakarma"). While laying any type of building or settlement layout Sthapati first places a coded chart and makes zone planning. That coded chart is called "Mandala " (Vastu Purush Mandala).

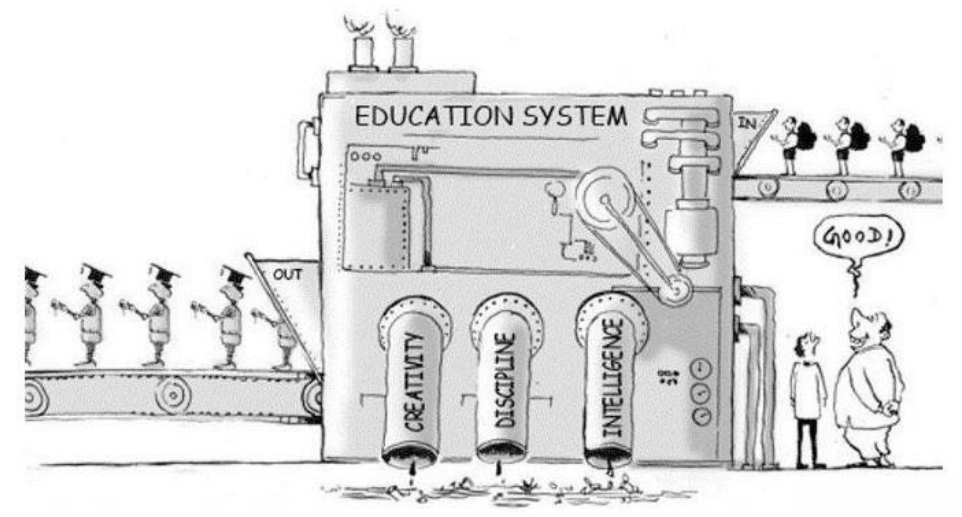

Fig 02 - Todays Architectural Education - Cartoonists İmpression

This architectural education is transferred with authenticity and integrity to the next generation to capable persons and preferably to sons from the same family. This transfer of special knowledge developed various techniques and methods in construction. Vastu Vidya (Building Science) has its first reference to the Rig-Veda (1500 BCE) that is 3500 years back and later on various treatises were written on it. The knowledge given in Rig-Veda shows that it was their common practice of constructing a building, hence it is having a reference to more thousands of years back. Some "Rishis' ' (Spiritual persons in Hinduism) say that it is having a base before the "Ramayana' ' period (10000 years back). It is surviving today because of fragmentary application by various conservation architects, craftsmen, rishi-muni, and astrologers. (Chakrabarti, 01998). Today's architectural education is far away from the traditional knowledge base. We are losing thousands of years of knowledge data and wasting our time for 
discovering another system of knowledge gaining. The current education system is not giving importance or neglecting ancestral architectural knowledge, philosophy, principles, and practices. In the Indian context, classical architectural Vastu Shastra practice is more important as it is related to nature, cosmos, and most important the spiritual life of the average person. It will be easier for the rural population to understand the Mandala concept and use it in their buildings because this coded chart has all the deities they pray to every day. Vastu Shastra has its second angle as "Green Energy Building"; it's very close to nature and merging with nature. Modern architectural materials are 90\% factory-made but in Vastu Shastra, most material is suggested from nature only and its least processed material.

The Vastu Shastra principles and practice both are related and important for the contemporary architectural education system. Previous sentences may be found not related to contemporary architectural practice, as today's settlements are based on demand for colonial industrial accommodation purposes. Buying luxurious life is easier as more income is possible. This modernity concept gives birth to various factory-made materials and concepts which are harmful to nature for the next thousands of years. (Environmental Science Europe 2018) (Heera Lomite, Sridhar Kare 2009). Indian academic teaching methods were changed from the 18th century and were more related to the western and European systems. The main purpose of this paper is to raise awareness of traditional architectural education needed in today's education system. To explain this classical philosophy and methods this is a strong base of ancient Vedic sciences to the youngsters. The Vedic architectural knowledge base (Vastu Shastra) is needed to simplify and remove mythological parts from it. The majority of the practitioners are ignoring this science or only partially using it to satisfy their clients. Academicians are also not taking an interest to teach such wonderful science, fundamentals of traditional Indian theory of architecture to the next generation only because they are also not familiar with these sciences.

Treatise "Mansara " explains very clearly the depth of this Vastu Vidya. The oldest other texts are Kautilya's Arthashastra, Mayamata, Samrangansutradhar, Rajavallabha, Vishvakarma Prakasha, and various other treatises. The theoretical part of these Vastu Shastra Sciences is given in various treatises and texts but the practical part is understood in detail only through the interaction with the Sthapati (Vastu Shastra Practitioner). Sthapati is majorly entrusted for various conceptions, designs, execution of new buildings, and conservations of old buildings (majorly temples).

\section{Philosophy of Vastu Shastra (Science for Buildings)}

Vastu Shastra is science for buildings with a philosophical base and practical explanations for how to give proper circulation within the building? How to build buildings? How to give proportion to the buildings? How to make categories for buildings? And many more questions and solutions about any type of development related to civil construction work. Vastu Purush Mandala is an extract of this Vastu Shastra knowledge. Vastu Shastra is a great combination of art and architecture. It explains not only the construction of the building but it gives details about how to decorate the building with various sculptures. This science for sculpture is a major part of Vastu Shastra and is called "Shilpa-Shastra ".

Any design process has three parts, concept, rationale, and tools required. These all three parts are illustrated in Vastu Purush Mandala in a grid pattern. Depending upon the type, function, complexity, and scale the Mandala can be drawn by thirty-two types. Symbolically one deity (god related to nature or 
climate) is placed in a specific square of the Mandala. We can say that there are building codes in the ancient Vedic era. This is applicable for sacred architecture and secular architecture also.

Any type of Mandala pattern always has a central space as open and called "Brahma Sthana". Vastu Purush Mandala is a concentric form diagram having spiritual and ritual significance in India. The division of sites in Mandala is given from one plot to one thousand twenty-four plots. This method of dividing plots is called "Pada Vinyas". In the treatise "Mansara " chapter seven and seventeen the details about "Padvinyas' ' are given. "Sthapati " (Architect), visualizes "Vastu Purush " while ritual making of padvinyas. Vastu Purush (Purush means Human) is the spirit of the site and he inhabits the site with face lying down. In Mansara Chapter seven "Padvinyas- Lakshanam " gives details about the arrangements of division plots. This is an interesting tool used in Vastu Shastra with geometrical and numerical principles of quadratic divisions. Therefore the arrangement of plots is always square. The proportion of the site becomes perfect with best use of the site and its conditions. This chapter gives thirty-two types of such arrangements.

\begin{tabular}{|c|c|}
\hline 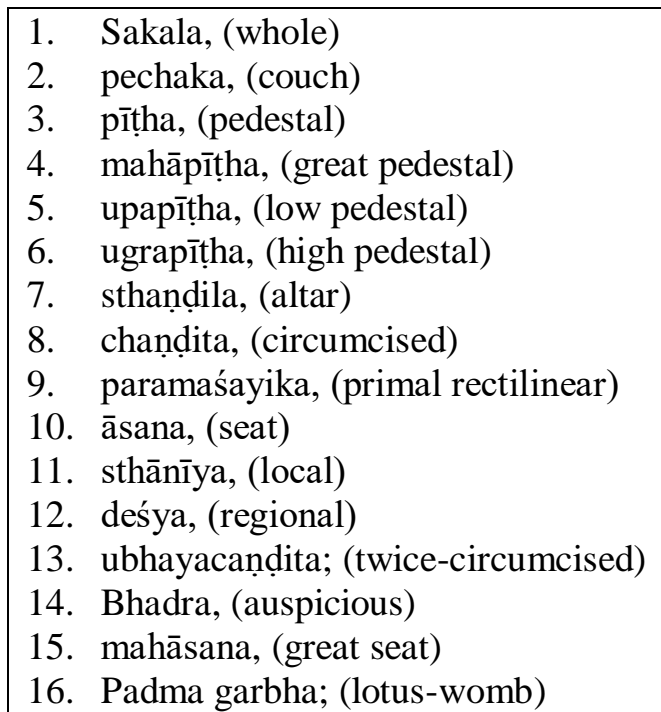 & $\begin{array}{l}\text { 17. triyuta; (thrice-yoked) } \\
\text { 18. karṇāșțaka, (eight-cornered) } \\
\text { 19. gaṇita; (computed) } \\
\text { 20. sūryavišālaka, (extensive as the sun) } \\
\text { 21. susaṃhita, (well-endowed) } \\
\text { 22. supratikānta, (beautiful rival-spouse) } \\
\text { 23. viśālaka, (capacious) } \\
\text { 24. vipragarbha, (Brāhmaṇa-womb) } \\
\text { 25. viśveśa; (lord of the world) } \\
\text { 26. vipula Hoga, (copious enjoyment) } \\
\text { 27. viprakānta; (Brāhmaṇa-spouse) } \\
\text { 28. viśālākșa, (large-eyed) } \\
\text { 29. viprabhakti, (Brāhmṇa's part) } \\
\text { 30. viśveśasāra, (the essence of lord of the world) } \\
\text { 31. iśvarakānta; (lord's spouse) } \\
\text { 32. Chandrakānta, (moon's spouse) }\end{array}$ \\
\hline
\end{tabular}

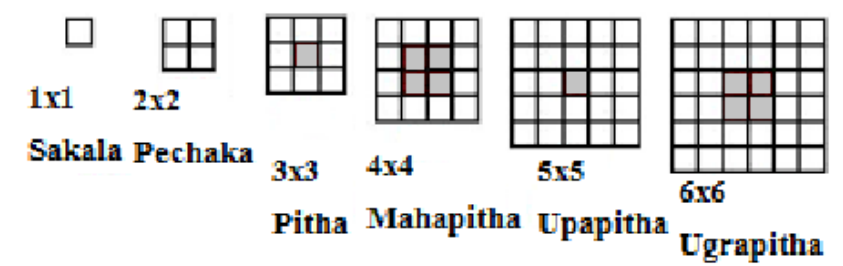

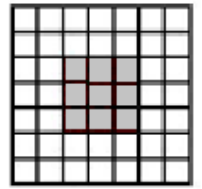

$7 \times 7$

Sthandila

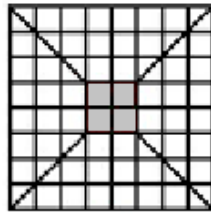

sxs

Manduka

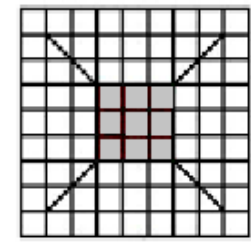

$9 \times 9$

Paramsayika
Fig - 03 - "Padvinyas", Arrangments of plots or rooms.
From above thirty-two, only seven arrangements are having more useful in practice in Vastu Shastra: Sakala, Pechaka, Pitha, Mahapitha, Upapitha, Manduka, and Paramasayika. After this Padvinyas (Arrangements) deities are placed in their specific square according to deities' principles.

Each type of arrangement of buildings is recommended for its specific use; like "Sakala Plan" is proposed for "Worship of gods", "for sacrifices with fire", "for daily dinner", "Pechaka Plan" is proposed for "public worship and public bath." (Acharya 2010). An architect can apply these principles of arrangements of plots for a specific 
site, use, and typology of the building.

In today's architectural education system the importance of the "grid plan concept" is explained with its structural benefits, but which type of grid will be useful to which type of specific use of a building is not given. The combination of this traditional and contemporary system of education will give good results in the architectural pedagogy world.

Modern architectural principles say how to align buildings with direction and the same thing or principle is given with its relation to nature and climate. The Vastu Purusha Mandala aligns the building with four cardinal (north, south, east, and west) and four ordinal directions (northeast, northwest, southeast, and southwest). Square Grid is a perfect form for site design and layout. The Intersection point of the square is called "Bindu". The Bindu point represents load caring points and "Sthamb's" (columns) are placed at the intersecting point and the void is open space or open volume of the room. Vastu Purush is not just a figure overlaid on a grid but it's more than that. (Vatsyayan, 1997). This Vastu Purush is a "Spirit of the site" and worshiped from time to time and mostly before inhabiting the building. The importance of "Vastu Purusha" is explained in the treatise "Samarangana Sutradhara". Surprisingly the position of "Vastu Purush " and the earth's axis direction is towards the northeast.

We can say that "Vastu Purush "is an imaginary human figure looking towards the earth and placed in between the Sun and Earth. Its interpretation is from the macro-level to micro-level, that's why the principals for large layout, fort, garden, palace, and small dwelling unit are the same. The navel place of Vatu Purusha is always kept open and symbolically related to the cosmos (Source of Energy) and stomach of human beings which is important for energy source and a place of "Vāyu" (Wind). Only the "Pechaka" type of Mandala does not have a central open space, but "Brahma Bindu" is present there.

Indian culture and philosophy are dependent upon or exist upon the outer world and inner soul, and the spiritual feelings and physical material desires. Vastu Purush is a symbolic representation of these interlinked macrocosmic and microcosmic worlds. Vastu Purush was also used as a measurement tool in ancient times.

A main "Sthapati" (Architect) himself was a measurement tool and he was also called Vastu Purush,

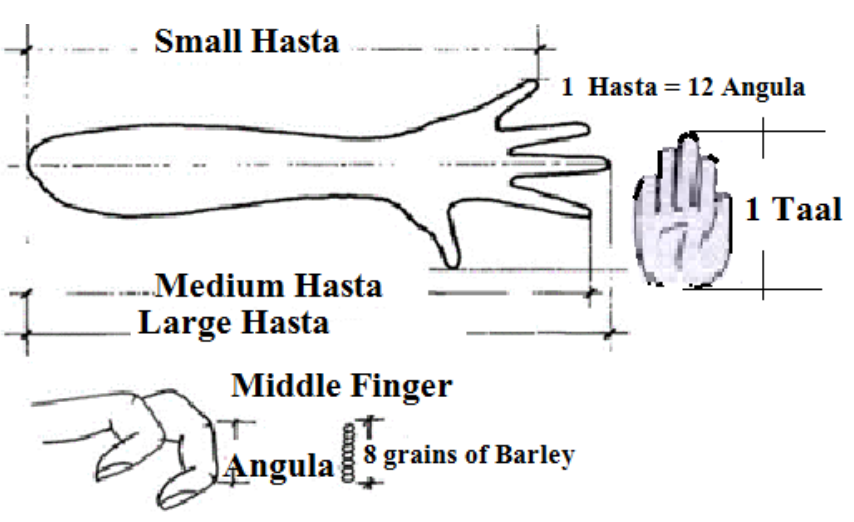

Fig 03A-System Of Measurments his "Hast" (Hand), "Anguli" (Finger), "Pada" (Leg) were common measurement tools and as per the perfect proportion of human beings the proportion of the structure is designed. Vatsyayan (1997) did more study of these proportions and symbolism of Vastu Purusha and mandala in her research. In her research, she found that this Vastu Purusha, Kal (concept of time), direction, and space were already used in "Natya Shastra" (Performing Arts). These concepts were later used as architectural principles in Vedic Vastu Shastra. 
In the Indian context, we found all deities are related to nature, some are related to basic five elements, some are related to direction, some are related to cosmos, some are related to planets, etc. The basic thought behind deities is that they are superpowers or which cannot be produced or which don't have birth and death. In Vedas, Puranas, Upanishads, and Brahmanas are showing these thoughts and

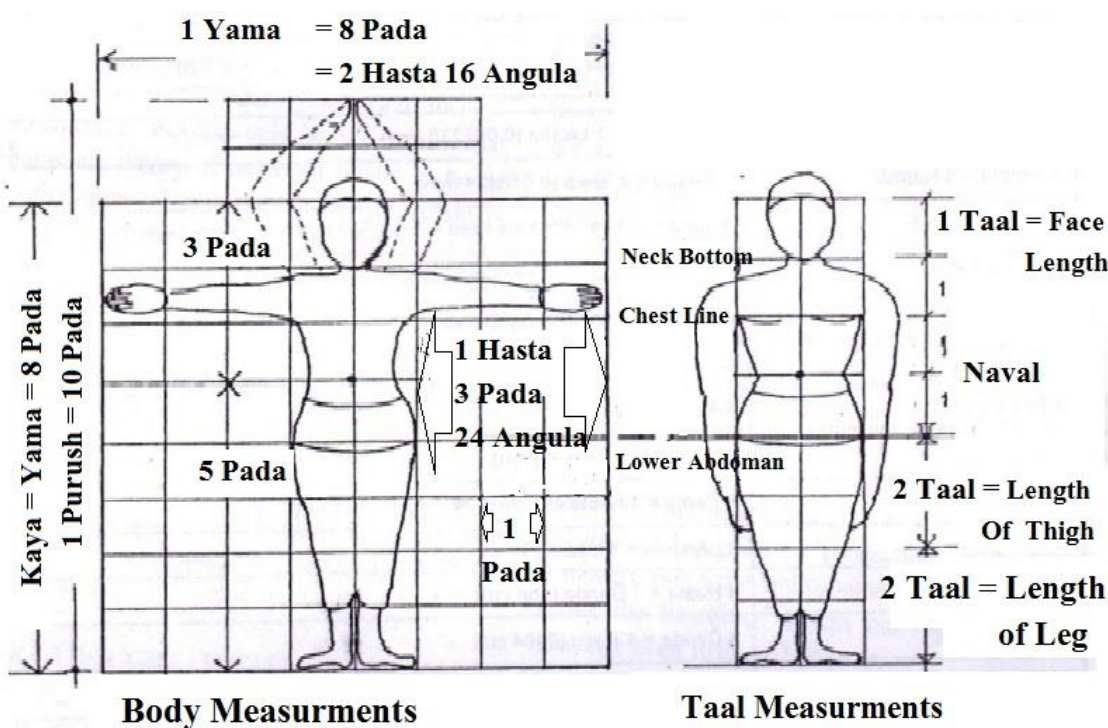

Fig 04 - Human Body Measurments as per Vastu Shastra (Golden Ratio)

ancient texts, treatises, and Mandalas. relationships between physical, psychical, metaphysical, macrocosmic, and microcosmic worlds. These relationship studies give a strong base to traditional architectural education (Vastu Shastra) and its theoretical and practical uses. This classical knowledge existed before the Vedic period and transformed to the Vedic period and then the medieval period. Some experts are still trying to save and pass this knowledge to the next generation. Full and in-depth knowledge of Mandala is key for architectural practice and concept developments. This old knowledge of sacred and secular buildings is embedded in various

There are eight fundamental components considered for the building or temple designs are bhūta (material), kāl (time), prakṛti (nature), diśās (directions), nakṣatras (planets), rasā (experience), yajna (ritual) and Purușa (the self). Vastu shastra design is based on symbolism and Purusha (Self) is a main part of design. Purusha is symbolically connected with other components and it reflects in every part of the building like a plinth, ceiling, projection, decorative carving, painting, etc. A clear thought of ancient experts is, what is found in atoms will be found in the universe ("Pindi te Brahmandi"). These eight fundamental components are supposed to release energy or stop the energy. Therefore the education system should have studied these linkages to make nature base designs to curtail cost and pollution as all non-renewable energy sources are responsible for pollution. Vastu Purusha Mandala is just not a colorful diagram or any type of mathematical grid; it's an energy field chart to make guidelines for the design process. Mandala is just not a tool to design but it is an extract of design. The construction site is not just physical ground only, but has a presence of all the energy sources from below ground and from the universe and is responsible for good or bad living habitats. Transmission of energy is important for the design process, and this process is easier in Vastu Mandala design. 
When we enclose space, it becomes a living organism. This enclosed space has its soul and has energy or life. When we talk about any type of building, sculpture, or ornamentation part we are talking about the living organism of that building, sculpture, or ornamentation part. Mantra, Yantra, and Tantra are used to build buildings in Vastu Shastra. Here "Mantra" is an evocation to gods (Super Natural Energies), "Yantra" is a plan of the building based on Mandala, and "Tantra" is a construction method used.
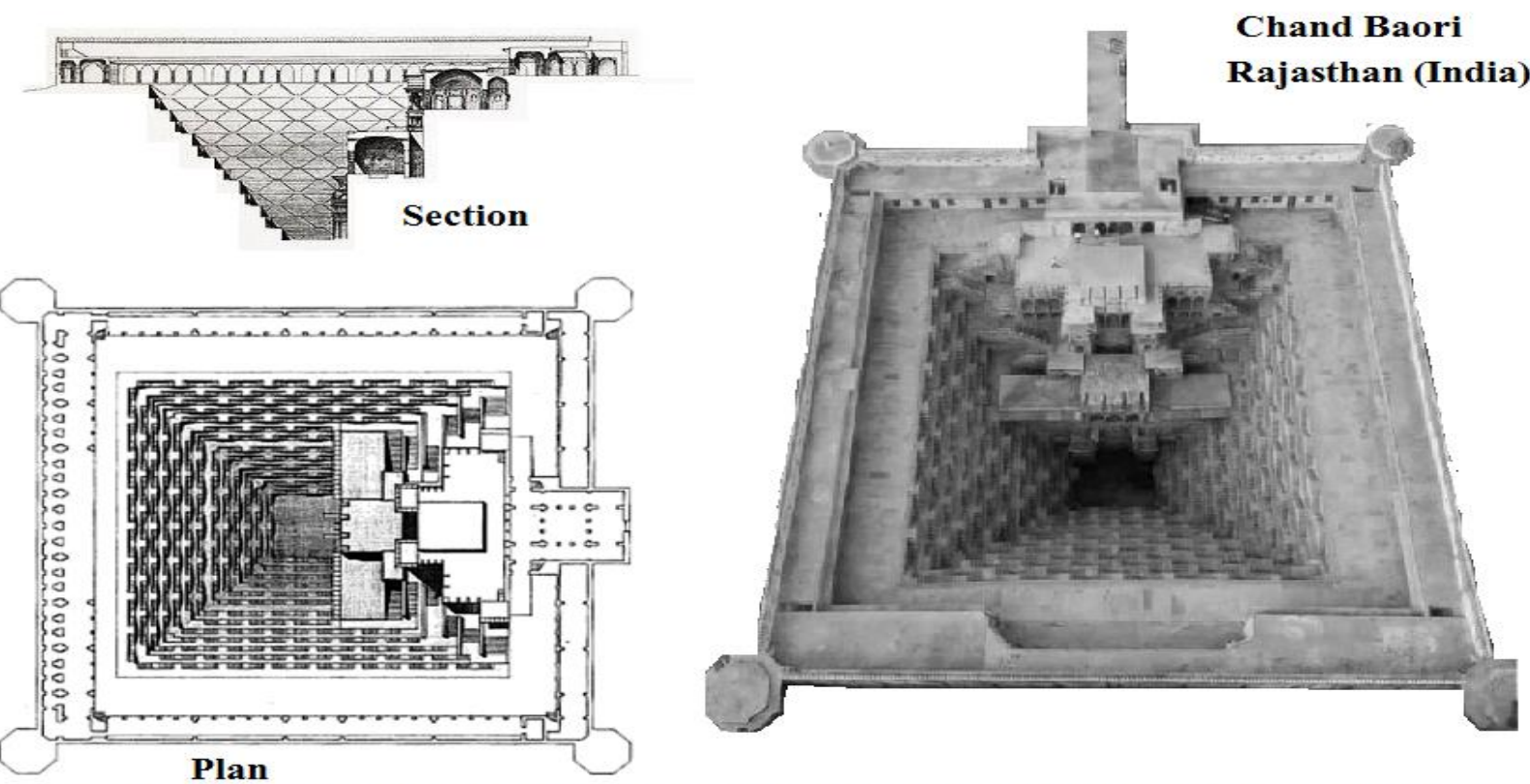

Fig 05 - Step wells like Chand Baori are excellent example of product of Vastu Shastra,this not possible without highly mathematical calculations and geometrical proportion.

We found various examples of buildings and places in the traditional and contemporary Indian context, which prove the relevance and use of ancient Vedic building knowledge. It was designed on the Vedic architectural principles of design and built according to the long-established construction methods. Step well like constructions required highly mathematical calculations and geometrical proportion knowledge. The proportions of these buildings are perfect and the materials used are basic materials from nature. Only fire bricks are processed and the pollution part is reduced to a least compared to today's context.

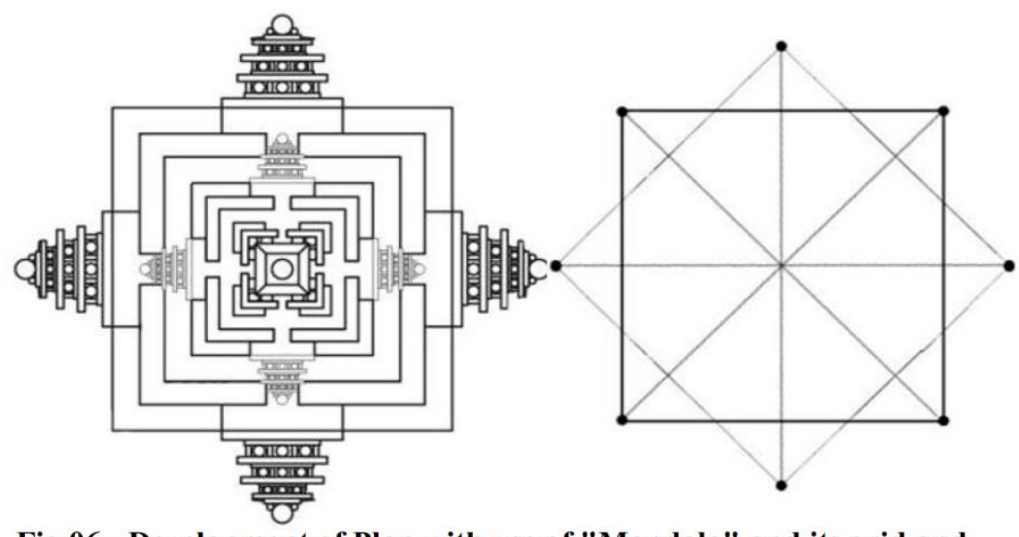

Fig 06 - Development of Plan with use of "Mandala" and its grid and bindu (Points), a deep use of geometrical forms and mathematical calculations. It will help in modern education system.
The use of traditional design principles in today's architectural education system is not satisfactory, although traditional design methods are easier for education and practice. The education system should consider the use of traditional knowledge, principles, concepts, and skills of design, as all are flourished in local areas and as per the requirement of the local community. The modern education system is having a global base and the most is not satisfactory in various parts of the globe. In 
Asia, we find sunny days more with high temperatures, but in the USA it's less. The education system teaches the use of glass facades for decoration, but in the Indian context, it is more pollution making as large glass facades need more air conditioning and more use of electricity which is having more pollution for its production. In India, we required just deep projections and least Southside openings to control temperature. Traditional knowledge and its fundamental aspects can be assessed with various indicators like experience, correlation, earlier references, innovations in methods and construction materials, trust, and future use of it.

\section{These indicators are useful and used as,}

Experience - Use of traditional knowledge in practice has plus and minus points per site conditions and experienced architects overcome the minus points and develops plus points per a combination of both traditional and contemporary systems.

Correlation - Usefulness, contents, and authenticity are limits to correlate traditional knowledge to contemporary education systems.

References - Source of knowledge (Traditional) is always easy to understand the use in practice as it has examples from day-to-day life and easy to find references nearby. Communication is easier with reference as it is proof of good work.

Innovation - Innovations are necessary to fulfill changing lifestyles and requirements of society. Traditional knowledge and contemporary methods both are useful and must be merged.

Trust - The information with true conclusions is a base of trust and traditional knowledge with its source of origin and its mediums must be trustworthy.

Knowledge Content - Knowledge content is always having important in the present and future also. True knowledge is having continuity and validity for the long term.

In the current scenario in India, the current education system has three main components, theoretical, applied, and practical. Council of Architecture, India derived these minimum standards of architectural education regulations (1983 / 2020).

The theoretical component has lectures, presentations, and seminars and is based on text learning. Surprisingly only 5\% is given as "History of Architecture" in which all the world's architectural history is given for study. If we calculate Indian Traditional architectural knowledge study, it will be below $0.5 \%$. COA (Council Of Architecture, India) is given some part in architectural guidelines for Indian traditional architectural treatises and other texts.

The applied component in a study is partly thinking and partly practices work, both requiring a local or traditional knowledge base. But the study language is also not Indian and the knowledge base is also not Indian. It increases complexity in the education process and difficulties for understanding the science to the students.

Practical components are important for exposure and are gained by working under experts in building design and construction. This component is having just $10 \%$ space in the education system and more the 
students are having just drafting work in their internship. Practical knowledge gain is not just from architectural firms but can be from carpentry workshops, artist's studios, or sculpturist.

All the components are interconnected and should have equal space in education. Interdependency of these three components increases the knowledge base in architectural education and will achieve the vision, aim, and objectives of education. It is argued that the current education system in India has drifted far away from its traditional education system in British rule. All education systems including architectural education are rearranged as per western work culture and it is service-oriented education to fulfill their demand of a new cadre of assistants. Today's content and education methods are Western or European systems of teaching. The use of the English language as a knowledge base plays the political agenda of Britishers and gives importance to education in the English medium. In some decades Sanskrit language was at the lower step of education although traditional knowledge is textured in the Sanskrit language. In the current decade, it's found that the education system is now coming back on indigenous education patterns.

Today It's helpful to have our ancestral architectural education method of learning, which is forgotten in some centuries. A combination of Mandala system planning and modern concepts for lifestyle will be milestones in the architectural world. A deep study is necessary before incorporating Vedic knowledge into the architectural education system. The questions are asked from the education experts are

1. What way the "Vastu Shastra " or "Vastu Mandala " will add value to architectural education?

2. Ancient knowledge and contemporary approaches will match or will create problems?

3. What to do about myths linked with Vastu Shastra?

4. Which measurement system should follow, globally accepted or human body measurements given in Vastu Shastra?

5. Study of gravitational forces of earth \& other planets is part of architectural education?

6. Studies of magnetic fields are important as per Vastu Shastra?

7. Is Astrology a science or not?

There are many questions we have to research and there is scope to develop or rewrite the classical Vedic education system with its meanings.

Modern architects or traditional Sthapati both are having a source of inspiration from the indigenous architectural philosophy of design and codified knowledge given in mandala. Historical knowledge is scattered in various texts and various Indian languages starting from Kashmir to Kanyakumari i.e. from the North to South end of India. This knowledge needs to be framed with contemporary architectural education. Value addition by adding a traditional knowledge base will prove relevance between the history of architecture in India and contemporary building knowledge. The references for practical components will be found from the last thousands of years in the way of temples, palaces, water bodies, and various types of settlements found on all the banks of rivers in India.

This paper shows possibilities of incorporating traditional knowledge of Vastu Shastra and Vastu mandala's knowledge content and design approaches. The merging of traditional knowledge to the contemporary education system will agree with the principles, concepts, contents, methods, tools, and skills of both traditional and modern systems. Vastu Mandala will be a theoretical component in architectural 
education and will offer a good philosophical base to design concepts. The theoretical component of Vastu Mandala in the architectural education system will connect to the applied component of education. It will give an analytical framework for exposure for designs.

Mandala as a basic knowledge hub will connect practical training sources for architectural education with having the best source for the design of Green Buildings or fewer pollution methods in building designs. This will give a different and innovative design experience.

\section{Conclusion}

The existing architecture education system has its origin in the western part of the world and is imposed on India. There is a huge difference between Indian culture and Western culture, the existing education system is a victim of this cultural difference. The inspiration of the current education system is coming from the western part of the world and it is not designed for the Indian context. Traditional Indian knowledge is neglected and dominated by contemporary education.

This paper recommends incorporating the traditional design knowledge base to contemporary education for theoretical, applied, and practical components. Vastu Purush Mandala has various qualities and is easy to understand as it is related to coded language in the spiritual culture of India. Mandala is a singlepage coded chart having information on cosmology, astrology, geography, and climate in India. This paper proposes the study of Mandala in the current education system for all three components, so this knowledge will be rooted again in culture and will help to reduce pollution and the requirement of non-renewable energy. Mandala will give effective tools and design methods in an indigenous way for time and space. Symbolism and Mandala and the philosophy behind it are more important to understand. Only symbolism generates various myths around it and society follows myths faster than philosophy.

This paper suggests an innovative design application process with the coded geometric pattern of Mandala, as it will be more authentic in society. In conclusion, the Vastu Mandala in the education system is the most wanted requirement with more study on its relations with modern material, latest techniques, changes in climate, and economy.

\section{Reference}

1. Jaffer A., Ayub K., Deepika V. (2016).Bindu and Mandala: Manifestations of Sacred Architecture. American Scientific Publishers

2. M. Shakya, "Basic Concepts of Mandala," Voice of History, vol. 15(1), pp. 81 - 88, 2000.

A. Mookerjee and M. Khanna, The Tantric Way - Art. Science. Ritual, London: Thames and Hudson, 1977.

3. E. E. Raddock, "Listen how the wise one begins construction of a house for Vișnu," Berkeley, 2011.

4. L. S. Thakur, "Application of Vāstupurașamaṇ̦ala in the Indian Temple Architecture: An Analysis of the Nāgara Temple Plans of Himachal Pradesh," Artibus Asiae, vol. 50, no. 3/4, pp. 263-284, 1990.

5. P. Xu, "The Mandala as a cosmic model used to systematically structure the Tibetan Buddhist Landscape," J Archit Plan Res, vol. 27, no. 3, pp. 181- 203, 2010.

6. S. Bafna, "On the Idea of the Mandala as a Governing Device in Indian Architectural Tradition," J Soc Archit Hist, vol. 59, no. 1, pp. 26 - 49, March 2000. 
7. Acharya, P. K. (1922). The training of architects in Ancient India. Rupam - an Illustrated Quarterly Journal of Oriental Art, 12.

8. Acharya P. K. (2010b). The architecture of Mānasāra: illustrations of architectural and sculptural objects. New Bharatiya Book Corporation.

9. Ananth, S. (1999). The place of tradition in design sensibility. Paper presented at the Symposium on new directions of architectural education - the necessity of a cultural paradigm responsive to the majority, GREHA, Delhi, India.

10. Archaeological Survey of IndiaSI. (2018). Archeological Survey of India, World Heritage Sites.

11. Vatsayana K. (1997), The Square and the Circle of the Indian Arts, Abhinav Publications

12. Chakrabarti, V. (1998). Indian architectural theory and practice: Contemporary uses of Vastu Vidya, Curzon.

13. Chhaya, H. D. (2004). Profession, education and regulatory bodies in India: a theme paper towards national dialogue. Architecture + Design India.

14. Cruickshank, D. (1987). Variations and traditions: the search for modern Indian architecture. The Architectural Review, August, 50-61.

15. Dagen, B. (1994). Mayamatam: the treatise of housing, architecture, and iconography. Indira Gandhi National Centre for the Arts. ISBN: 81-208-1226-3.

16. Kramrisch, S. (1946). The Hindu temple. The University of Calcutta.

17. Mehta, J. (2001). Towards a new pedagogy. Architexturez Imprints

18. Menon, A. G. K. (2000). Educating the architect. Seminar (India) Magazine, no. 494.

19. Piplani, N. \& Brar, T. S. (2020). Traditional building knowledge: Contemporary relevance for architecture education in India. The International Journal of Design Education, 14(2), 89-102.

20. Sachdev, V. (2011). Paradigms for design: the Vastu Vidya codes of India. In S. Marshall (Ed.), Urban coding and planning (pp. 83-100). Routledge. ISBN 978-0-415-44127-8 (Pbk)

21. Jacob, JOse, (2003), The Architectural Theory Of The Mansara, McGill University, (Thesis)

22. Nicole B., Stefan G., Outi L., Ute S. (2018) Evaluation of the impact of construction products on the environment by leaching of possibly hazardous substances, Environmental Science Europe, Vol 30, Article no. 14 (2018)

23. IAFOR Journal of Education: Studies in Education Volume 8 - Issue 4 - 2020174 